of negative social consequences, as demonstrated by the different connotations of 'sissy' and 'tomboy'. For girls with $\mathrm{CAH}$, there is another social issue: many undergo genital surgery in infancy and have impaired fertility. Girls' knowledge about their condition may trigger concerns about their femininity and lead to an avoidance of toys such as dolls.

To some extent, both books are brooms that sweep too clean. I contend that one cannot dismiss sex differences in mental rotation of three-dimensional objects as ill-documented or easily reversed, as both authors do. The difference is robust and difficult to neutralize; its precursors are seen in infancy. Laying such distinctions only at the doorstep of social psychology - in different expectations of the two sexes, for example closes off inquiry into underlying cognitive processes. Similarly, there is almost nothing about sex differences in mathematics and science in Jordan-Young's book, and only a cursory treatment in Fine's.

I share both authors' conclusions that the jury is still out over whether hormonal and neural sex differences are linked to behavioural divergence. I also agree that social context is often a more likely source of sex differences. Most behavioural sex differences are small, and there is no direct mapping between a behaviour and a set of neural mechanisms. Different neural mechanisms can be responsible for the same behaviour.

It is no bad thing that there are many hypotheses still to test. Eventually, unsupported preconceptions about what counts as masculine and feminine will be discarded. Until then, people such as Fine and JordanYoung are just who we need.

Virginia Valian is professor of psychology and co-director of the Gender Equity Project at Hunter College, City University of New York, New York 10065, USA.

e-mail:virginia.valian@hunter.cuny.edu

\title{
Answers from the Atacama
}

\section{A Chilean film juxtaposes astronomy with the search for those killed under Augusto Pinochet, finds Alison Abbott.}

$\mathrm{T}$ The Atacama Desert in northern Chile is the driest place on Earth. Decades can pass with no rain. Patricio Guzmán tells the stories of the people who are searching in its arid expanse in his film Nostalgia de la Luz (Nostalgia for the Light) - winner of the 2010 European Film Academy award for best documentary and now showing in selected cinemas in Europe. On the desert's mountain tops, astronomers look skyward, hunting for cosmological truths. On its plains, others look towards the ground, hunting for political truths.

Astronomers love the Atacama. Its dryness and clear skies give them an unimpeded view of deep space. Since the mid-1960s, they have been building ever-more powerful telescopes there with which to gaze ever farther into the cosmos. Piecing together the history of the Universe from the ancient light of distant stars, they are largely unaware of the women below on the desert floor, digging - sometimes with their bare hands - for the remains of loved ones killed during the regime of dictator Augusto Pinochet in the 1970s.

Nostalgia de la Luz interweaves the stories of these two searches - one addressing modern history on a heartbreakingly human scale, the other deep history on a grandiose and edifying scale. Other scientific investigations also feature, including archaeology. It is a slow, poetic film that contemplates existential questions: where we
For more on the spirit of observatories: go.nature.com/ehdlon

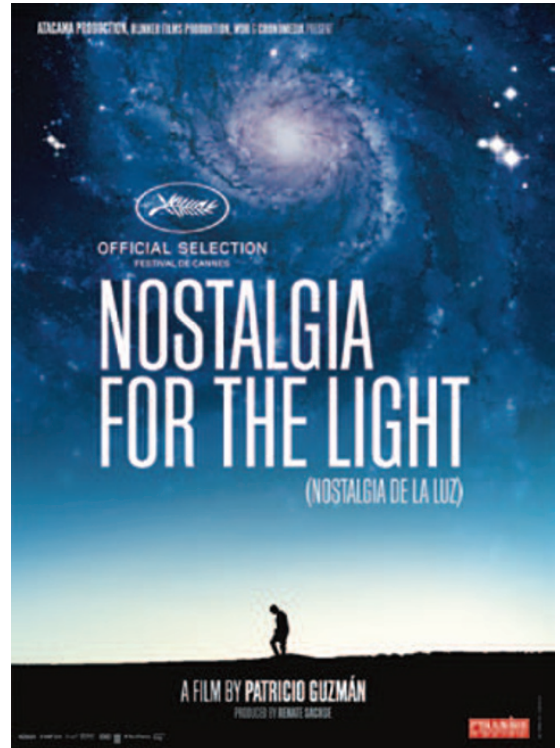

Nostalgia de la Luz

DIRECTED BY PATRICIO GUZMÁN

In some independent cinemas in Europe.

came from, where we are going and how we come to terms with the pain of the present. It is compelling, thanks to the characters that the director has found to explain their quests.

Gaspar is an articulate young Chilean astronomer working at the Cerro Tololo observatory, who can answer many questions about cosmic history but few about his country's recent past, when thousands disappeared or were killed and traces of their fate covered up. Lautaro is an older archaeologist who followed the trails of ancient civilizations through the desert for decades, finding their mummified dead in the desiccating atmosphere. Now he teaches the searching women how to recognize from the surface grains whether a human body might lie below the sand.

Also featured is Luís. He spent years in one of Pinochet's concentration camps in the desert, where he learnt about astronomy from a fellow political prisoner. Stargazing helps him not to forget that time, he says. Miguel, an architect, survived five such camps. He committed their layouts to memory and drew them up precisely when he was freed, so that Chileans would never be able to deny their existence.

Towards the end of the dictatorship, Pinochet's soldiers dug up mass graves and dumped evidence of the massacres in the sea. The film follows Victoria and Violeta, who talk movingly about their continuing search for their loved ones. They have found fragments of their bones, smashed by the digging machinery, which has fed their determination to find out what happened.

And there is Valentina, whose mother and father were among those who disappeared, who became an astronomer after the grandparents who raised her taught her to observe the night sky. Understanding the infinite Universe, she says, has given her a comforting perspective on her loss.

Guzmán, the film's director, is himself a refugee from Pinochet's Chile, and now lives in France. Most of his films have been political, and this venture into science provides him with metaphors of immense power with which to explore this theme. Nostalgia de la Luz will also confront scientists with connections that they have not previously imagined. If only, the searching women say, the telescopes could instead point downwards to help them.
Alison Abbott is Nature's European correspondent. 